\title{
Säilöntäaineen ja kuiva-ainepitoisuuden vaikutus säilöheinän laatuun
}

\author{
Seija Jaakkola ${ }^{1)}$, Eeva Saarisalo ${ }^{2)}$ ja Terttu Heikkilä ${ }^{3)}$ \\ ${ }^{1)}$ Helsingin yliopisto, Maataloustieteiden laitos, PL 28, 00014 Helsingin yliopisto, \\ etunimi.sukunimi@helsinki.fi \\ ${ }^{2)}$ Maa- ja metsätalousministeriö, elintarvike- ja terveysosasto, PL 30, 00023 Valtioneuvosto, \\ etunimi.sukunimi@mmm.fi \\ ${ }^{3)}$ MTT, Kotieläintuotannon tutkimus, 31600 Jokioinen, etunimi.sukunimi@mtt.fi
}

\section{Tiivistelmä}

Säilöheinä on kuiva-ainepitoisuudeltaan (450-800 g/kg) säilörehun ja kuivan heinän välimuoto, jota käytetään runsaasti erityisesti hevosten ruokinnassa. Säilöheinän tekotapa vastaa enemmän säilörehua, koska kostea rehu säilötään ilmatiiviisti, yleensä muovitettuihin paaleihin. Säilöheinän säilöntäprosessia ja säilyvyyteen sekä erityisesti jälkipilaantumisalttiuteen vaikuttavia tekijöitä on tutkittu selvästi vähemmän kuin tuoreemman rehun. Nurmikasvien vesiliukoisten hiilihydraattien, sokereiden, pitoisuus voi vaihdella suuresti. Hevosen ruokinnassa vesiliukoisiin hiilihydraatteihin kuuluvien fruktaanien suuren määrän on esitetty vaikuttavan hevosten kaviokuumealttiuteen. Säilönnän vaikutus rehun sokeripitoisuuteen voi siten olla tärkeä rehun ruokinnalliseen laatuun vaikuttava tekijä.

Erityyppisten säilöntäaineiden vaikutusta säilöheinän koostumukseen ja lämpenemisherkkyyteen eli aerobiseen stabiilisuuteen tutkittiin kahdessa kokeessa, joista toinen tehtiin koemittakaavassa (3-4 kg/siilo) ja toinen pyöröpaaleissa. Ensimmäisen osakokeen rehut tehtiin kahdessa kuiva-ainepitoisuudessa (510 ja $600 \mathrm{~g} / \mathrm{kg}$ ). Mukana oli kaksi propionihappoon perustuvaa kemiallista säilöntäainetta ja kolme maitohappobakteereihin perustuvaa biologista valmistetta. Pyöröpaalikokeen rehut tehtiin kolmessa kuiva-ainepitoisuudessa $(450,550$ ja $650 \mathrm{~g} / \mathrm{kg})$. Mukana oli yksi propionihappovalmiste ja kolme biologista valmistetta, joista osa oli samoja kuin ensimmäisessä osakokeessa.

Sekä kuiva-ainepitoisuus että säilöntäaine vaikuttivat rehujen käymisprosessiin ja sitä kautta esimerkiksi maitohappo- ja sokeripitoisuuteen. Myös lämpenemisherkkyydessä oli eroja. Ensimmäisessä kokeessa kuivempien rehujen lämpeneminen alkoi aikaisemmin. Propionihappopohjaiset säilöntäaineet ja Lactobacillus plantarumin + L. buchnerin yhdistelmä olivat tehokkaita lämpenemisen estäjiä. Toisessa kokeessa kuiva-aineen vaikutus oli erilainen eri säilöntäkäsittelyiden yhteydessä. Tehokkaimmin lämpenemistä esti propionihappoon perustuva säilöntäaine. Lähes yhtä hyvä oli L. plantarumin ja natriumbentsoaatin yhdistelmä. L. plantarumin ja L. buchnerin yhdistelmä ei sen sijaan ollut yhtä tehokas kuin ensimmäisessä kokeessa. Biologiset valmisteet pienensivät rehun sokeripitoisuutta säilönnän aikana, mutta happovalmisteiden vaikutus oli hyvin vähäinen. Mitä kuivempaa rehu oli, sitä vähemmän sokeripitoisuudessa tapahtui muutosta.

Säilöheinän laatuun voidaan vaikuttaa päätöksillä, jotka koskevat rehun esikuivatusaikaa ja säilöntäaineen käyttöä. Rehun kuivattaminen suureen kuiva-ainepitoisuuteen (yli $550 \mathrm{~g} / \mathrm{kg}$ ) lisää riskiä rehun lämpenemisestä verrattuna tuoreempaan rehuun ja suuri kuiva-ainepitoisuus myös säilyttää rehussa suuren sokeripitoisuuden. Säilöntäaineen käyttö parantaa rehun mikrobiologista laatua ja sitä kautta pienentää myös lämpenemisriskiä. Lämpenemisen estäjänä tehokkaimmaksi osoittautui propionihappopohjainen valmiste. Myös maitohappobakteerin ja natriumbentsoaatin yhdistelmä antoi hyvän tuloksen. Propionihapon käyttö ei vähentänyt säilöheinän sokeripitoisuutta säilönnän aikana. Sen sijaan maitohappobakteereiden käyttö säilöntäaineena muuntaa tehokkaasti rehun sokereita maitohapoksi. Siten se on tehokas keino vähentää rehun sokeripitoisuutta ja myös fruktaaneiden pitoisuutta, jos tavoitteena on rehun sokeripitoisuuden vähentäminen hevosten ruokinnassa. Edellytyksenä on kuitenkin, että rehua ei kuivata liian kuivaksi. Kuiva-ainepitoisuuden on oltava alle $550 \mathrm{~g} / \mathrm{kg}$, jotta maitohappokäymistä voi tapahtua riittävästi.

Asiasanat: säilöheinä, sokeri, lämpeneminen, säilöntäaine, maitohappobakteerit, propionihappo 


\section{Johdanto}

Säilörehun teko perustuu hapettomuuteen ja happamuuteen, jotka estävät pilaajamikrobien toiminnan. Happamuus syntyy anaerobisen maitohappokäymisen ja säilöntäaineen avulla. Käymisprosessia ylläpitävät maitohappobakteerit tarvitsevat vettä toimiakseen, eli rehussa on oltava riittävästi kosteutta. Kuivan heinän säilyminen perustuu puolestaan veden vähyyteen, joka estää pilaajamikrobien toiminnan. Säilöheinä tulee englannin kielen sanasta haylage, joka on kuivan heinän (hay) ja säilörehun (silage) välimuoto. Säilöheinän kuiva-ainepitoisuus voi olla $450-800 \mathrm{~g} / \mathrm{kg}$ ja rehu varastoidaan ilmatiiviisti, useimmiten muovitettuihin paaleihin. Säilöheinässä tapahtuu jonkin verran anaerobista käymistä, joten se muistuttaa enemmän säilörehua kuin heinää. Säilöheinän voi korjata kasvuston samassa kehitysvaiheessa kuin säilörehun. Hevosille säilöheinä korjataan kuitenkin usein myöhemmin kuin säilörehu lypsylehmille ja toisaalta aikaisemmin kuin perinteinen kuiva heinä. Kasvuston kehitysaste vaikuttaa sulavuuden lisäksi rehun säilyvyyteen. Kortinen kasvi vaikeuttaa rehun tiivistämistä ja voi aiheuttaa suojamuovin rikkoutumisen, jolloin säilymiselle tärkeää anaerobisuutta ei saavuteta.

Aerobinen stabiilisuus kuvaa siilon tai paalin avaamisen jälkeistä rehun lämpenemisherkkyyttä ja samalla epäsuorasti rehun mikrobiologista laatua. Voimakkaasti esikuivatut rehut ovat usein herkkiä lämpenemään. Niissä pilaajat ovat pääasiassa hiivoja ja homeita, joiden toimintaa voidaan rajoittaa estämällä ilman pääsy rehuun mahdollisimman tehokkaasti sekä käyttämällä säilöntäaineita. Propionihappo, etikkahappo, bentsoehappo ja sorbiinihappo ovat tunnettuja homeiden ja/tai hiivojen estäjiä, joita on käytetty myös rehunsäilönnässä (Woolford 1975, Saarisalo ym. 2006). Kemiallisten säilöntäaineiden lisäksi on rehun aerobista stabiilisuutta pyritty parantamaan käymisprosessia muuntamalla. Lactobacillus buchneri on maitohappobakteeri, joka tuottaa maitohapon lisäksi etikkahappoa ja propaanidiolia, joilla on erityistä fungisidistä vaikutusta enemmän kuin maitohapolla (Oude Elferink ym. 2001). Arvioitaessa erilaisten valmisteiden käyttömahdollisuuksia säilönnässä on otettava huomioon, että niiden tehokkuuteen vaikuttavat sekä rehun kuiva-ainepitoisuus että $\mathrm{pH}$.

Hevosten ruokinnassa rehun suuri sokeripitoisuus ja etenkin fruktaanipitoisuus on yhdistetty kaviokuumealttiuteen (Pollit ym. 2003). Nurmikasvuston sokeripitoisuuteen vaikuttavat kasvilaji ja kasvilajike sekä monet kasvuolosuhdetekijät (typpilannoitus, lämpötila, päivän pituus, vesi). Niiton jälkeen rehun sokeripitoisuuteen vaikuttavat esikuivatusajan pituus ja olosuhteet sekä rehun lopullinen kuiva-ainepitoisuus ja säilönnässä käytettävä säilöntäaine. Mitä kuivempaa rehu on, sitä rajoittuneempaa on käyminen ja sitä suurempi on rehun sokeripitoisuus. Toisaalta maitohappokäymistä rajoittavat säilöntäaineet (hapot) ylläpitävät sokeripitoisuutta ja käymistä edistävät aineet (ns. biologiset säilöntäaineet) vähentävät pitoisuutta.

Tämän tutkimuksen tavoitteena oli selvittää, kuinka esikuivatus ja säilöntäaineen käyttö vaikuttavat säilöheinän koostumukseen ja säilönnälliseen laatuun. Tutkimuksessa tehtiin kaksi erillistä koetta, joissa määritettiin rehun kuiva-ainepitoisuuden ja erityyppisten säilöntäaineiden vaikutus erityisesti rehun sokeripitoisuuteen ja aerobiseen stabiilisuuteen.

\section{Aineisto ja menetelmät}

Säilöntäkokeet tehtiin vuosien 2006 ja 2007 ensimmäisestä sadosta Jokioisten Kartanoiden (JKA) Lintupajun lohkolta L5, jossa oli toisen (2006) ja kolmannen (2007) vuoden timotei-nurminatanurmi. Ensimmäisen vuoden kokeessa kasvusto niitettiin 19.6. klo 9 niittomurskaimella ja esikuivattiin kahteen kuiva-ainepitoisuuteen. Ensimmäiset rehut tehtiin 26 tunnin kuivatuksen jälkeen kuiva-ainepitoisuuden ollessa $513 \mathrm{~g} / \mathrm{kg}$ (KA1). Toisen rehuerän kuivatusaika oli 29 tuntia ja kuiva-ainepitoisuus 601 g/kg (KA2). Esikuivatuksen jälkeen ruoho kerättiin karholta pyöröpaalaimella, jotta silpun pituus vastaisi pyöröpaalattua rehua. Paalaimella kerätystä ruohosta otettiin näyte ja säilöntäainelisäyksen jälkeen ruoho säilöttiin koesiiloihin (siilokoko $12 \mathrm{dm}^{3}$ ). Painorehun lisäksi säilöntäaineainekäsittelyitä oli viisi, joista kaksi oli propionihappoon perustuvia kemiallisia säilöntäaineita ja kolme maitohappobakteereihin perustuvia biologisia valmisteita (taulukko1). Kutakin käsittelyä tehtiin kolme rinnakkaissiiloa. Rehusiilot avattiin 118 päivän säilönnän jälkeen.

Toisena vuotena kasvusto niitettiin 18.6. klo 10.00 - 11.30 niittomurskaimella ja esikuivattiin kolmeen kuiva-ainepitoisuuteen. Esikuivatusajat olivat 24, 30 ja 50 tuntia ja raaka-aineiden kuivaainepitoisuudet vastaavasti 440 (KA1), 560 (KA2) ja 643 (KA3) g/kg. Mukana oli yksi propionihappovalmiste ja kolme biologista valmistetta, joista osa oli samoja kuin ensimmäisessä osakokeessa. 
Taulukko 1. Säilöntäainekäsittelyt kokeissa 1 ja 2.

\begin{tabular}{|c|c|c|c|}
\hline Säilöntäaineiden koostumus ja annostus & Koodi (kauppanimi) & Koe 1 & Koe 2 \\
\hline Ei säilöntäainetta, painorehu & PR & $\mathrm{X}$ & $\mathrm{X}$ \\
\hline $\begin{array}{l}\text { Propionihappo } 43 \% \text {, ammoniumpropionaatti } 27 \% \text {, } \\
\text { vesi } 30 \%, 81 / \mathrm{t}\end{array}$ & PrH (Topform) & $X$ & $\mathrm{X}$ \\
\hline $\begin{array}{l}\text { Propionihappo } 43 \% \text {, ammoniumpropionaatti } 27 \% \text {, } \\
\text { vesi } 27,5 \% \text {, kaliumsorbaatti } 2,5 \%, 71 / \mathrm{t}\end{array}$ & PrH-S (Topform S) & $X$ & \\
\hline $\begin{array}{l}\text { Lactobacillus rhamnosus LC705 (DSM7061), Propionibac- } \\
\text { terium freudenreichii ssp. shermanii JS (DSM7067), } 10^{6} \\
\text { pmy/g }\end{array}$ & LR-PF (AIVBioprofit10) & $\mathrm{X}$ & \\
\hline Lactobacillus plantarum (VTT E-78076), $10^{6}$ pmy/g & LP (LactoFast) & $\mathrm{X}$ & \\
\hline $\mathrm{LP}, 10^{6} \mathrm{pmy} / \mathrm{g}+$ L. buchneri $\left(\mathrm{VTT}\right.$ E-93445), $10^{5} \mathrm{pmy} / \mathrm{g}$ & LP-LB & $X$ & $\mathrm{X}$ \\
\hline $\mathrm{LP}, 10^{6} \mathrm{pmy} / \mathrm{g}+$ natriumbentsoaatti, $300 \mathrm{~g} / \mathrm{t}$ & \multicolumn{2}{|c|}{ LP- NaB (LactoFast-Nabfast) } & $X$ \\
\hline Lactobacillus rhamnosus, $5 \times 10^{5} \mathrm{pmy} / \mathrm{g}$ & \multicolumn{2}{|c|}{ LR (Bioprofit R) } & $X$ \\
\hline
\end{tabular}

Topform, TopformS, LactoFast, LactoFast-Nabfast, Kemira Oyj; AIV Bioprofit, Bioprofit R Valio Oy

Kaikissa kuiva-ainepitoisuuksissa pyöröpaaleja tehtiin kolme rinnakkaista viidellä säilöntäainekäsittelyllä (taulukko1). Säilöntäaineen kulutus mitattiin paalikohtaisesti. Propionihappovalmisteen annostus toteutui suunnitelman mukaisesti ainoastaan KA3 rehuissa (keskiarvo 8,2 1/t) ollen KA1 (4,7 1/t) ja KA2 (6,8 1/t) rehuissa tavoitetta pienempi.

Paalain oli kiinteäkammioinen, silppuava ja verkkosidonnalla varustettu Claas Rollant 250 Roto Cut (vastateriä 14) varustettuna Elho ProFlow 4000-hapottimella. Paalit kuljetettiin käärintäpaikalle Euro-sovitteisella Quicke Flexigrip-paalipihdillä, punnittiin paalivaa'alla ja kiedottiin muovilla. Kiedontalaite oli Kverneland 7517, kiedontamuovi $750 \mathrm{~mm}: n$ kotimaista valkeaa RaniWrap-paalikiristekalvoa. Kiedonnassa käytettiin 50 \%:n limitystä ja $70 \%$ :n esikiristystä ja 6 kerrosta. Paalit sijoitettiin tasaiselle alustalle pellon laitaan. Paaleista kairattiin näytteet eri puolilta kolmessa erässä 19.11.2007, 3.12.2007 ja 14.1.2008. Keskimäärin paalien säilöntäaika oli 177 päivää.

Raaka-ainenäytteistä määritettiin tuhka, raakavalkuainen, neutraalidetergenttikuitu (NDF), pelkistävät sokerit, liukoinen N, puskurikapasiteetti ja in vitro sulavuus sellulaasimenetelmällä. Säilörehuista määritettiin tuhka, $\mathrm{pH}$, raakavalkuainen, maitohappo, haihtuvat rasvahapot (VFA), pelkistävät sokerit, etanoli, liukoinen $\mathrm{N}$ ja ammonium N. Näytteet analysoitiin Helsingin yliopistossa. Aerobinen stabiilisuus määritettiin MTT:llä seuraamalla rehun lämpötilan muutosta sen joutuessa ilman vaikutuksen alaiseksi. Säilörehujen koostumustiedot ja aerobisen stabiilisuuden tulokset testattiin varianssianalyysillä SAS:n GLM ohjelmalla. Käsittelyjen neliösumma jaettiin ortogonaalisiin, yhden vapausasteen kontrasteihin.

\section{Tulokset ja tulosten tarkastelu \\ Piensiilokoe (koe 1)}

Raaka-aineiden koostumukset on esitetty taulukossa 2. Sekä kuiva-ainepitoisuus että säilöntäaine vaikuttivat rehujen käymisprosessiin ja sitä kautta happamuuteen sekä maitohappo- ja sokeripitoisuuteen. Maitohappobakteerivalmisteet (ympit) lisäsivät molemmissa kuiva-ainepitoisuuksissa maitohappokäymistä ja laskivat rehun $\mathrm{pH}: n$ alemmaksi painorehuun ja propionihapolla käsiteltyihin ( $\mathrm{PrH}, \mathrm{PrH}-\mathrm{S})$ rehuihin verrattuna (taulukko 3). Käymisen seurauksena ymppirehujen sokeripitoisuus oli pienempi kuin hapolla säilöttyjen rehujen. Kuivemmassa rehussa $\mathrm{pH}$-arvo ja sokeripitoisuus olivat suuremmat KA1 rehuihin verrattuna. Kuitenkin LP ja LP-LB käsittelyt tuottivat melko runsaasti maitohappoa vielä $\mathrm{KA} 2$ rehussakin $(36-40 \mathrm{~g} / \mathrm{kg} \mathrm{ka})$. Tulos osoittaa hyvin säilöntäaineen mahdollisuudet rehun sokeripitoisuuden säätelyssä. Toisaalta mitä kuivempaa rehu on, sitä vähemmän tapahtuu käymistä ja 
sitä suurempi osuus sokerista jää rehuun. Kokeessa jo melko pieni ero kuiva-ainepitoisuudessa (88 $\mathrm{g} / \mathrm{kg}$ ) vaikutti oleellisesti sokerin ja siitä muodostuneen maitohapon osuuksiin.

Ammoniakin ja VFA:n muodostuminen oli hyvin rajoittunutta kaikissa rehuissa. Suuret propionihapon (taulukossa VFA:ssa) ja ammoniakin pitoisuudet $\mathrm{PrH}$ ja $\mathrm{PrH}-\mathrm{S}$ rehuissa olivat seurausta säilöntäaineessa lisätyistä määristä. Tästä johtuen kyseisten rehujen ammoniakki- ja VFA-pitoisuudet eivät kuvaa säilönnän onnistumista. Voihappoa todettiin vain hieman eli $0,23-0,34 \mathrm{~g} / \mathrm{kg}$ ka. Näin kuivien rehujen ongelma ei ole virhekäyminen tai valkuaisen runsas hajoaminen kuten tuoreempien rehujen. Ongelmia aiheuttavat pääasiassa aerobiset haittamikrobit kuten hiivat ja homeet.

L. buchnerin yhteiskäyttö L. plantarumin kanssa vähensi maitohapon ja lisäsi ammoniakin ja VFA:n pitoisuutta KA1 rehussa verrattuna pelkän $L$. plantarumin käyttöön. VFA:n lisäys tuli pääasiassa etikkahapon määrän lisääntymisestä. Kuivemmassa rehussa yhdistelmä laski pH:ta, vähensi sokeripitoisuutta ja lisäsi maitohapon ja etikkahapon pitoisuuksia. Edellä mainitut vaikutukset olivat tilastollisesti merkitseviä, mutta numeerisesti hyvin pieniä. Kaliumsorbaatin lisäys propionihappovalmisteeseen ( $\mathrm{PrH}$ vs $\mathrm{PrH}-\mathrm{S}$ ) ei vaikuttanut oleellisesti rehun käymisprosessiin.

Aerobinen stabiilisuus oli numeeristen arvojen perusteella parempi tuoreempana korjatuissa rehuissa kuin kuivemmissa (kuvio 1). Säilöntäaineiden käyttö vähensi merkitsevästi rehujen lämpenemisherkkyyttä painorehuun verrattuna. Säilöntäaineiden välillä ei ollut merkitseviä eroja KA1 rehuissa. Kuivemmassa rehussa LP ja LP-LB rehut olivat stabiilimpeja kuin LR-PF rehut. Tähän eroon vaikutti erityisesti LP-LB rehun hyvä stabiilisuus. Ero LP ja LP-LB:n välillä ei kuitenkaan ollut tilastollisesti merkitsevä. Kaliumsorbaatin yhteiskäyttö propionihapon (PrH-S) kanssa ei parantanut aerobista stabiilisuutta pelkkään propionihappoon (PrH) verrattuna kummassakaan kuiva-ainepitoisuudessa.

\section{Paalikoe (koe 2)}

Eri säilöntäaineiden vaikutus rehu happamuuteen painorehuun verrattuna vaihteli kuiva-ainepitoisuuksittain (taulukko 4). Propionihappovalmiste esti käymisen kaikissa kuiva-aineluokissa, joten $\operatorname{PrH}$ rehun $\mathrm{pH}$ oli lähes muuttumaton (keskiarvo 5,27). Painorehuissa kuiva-ainepitoisuuden lisääntyminen esti maitohappokäymisen lähes kokonaan KA2 ja KA3 rehuissa. Tästä johtuen kuiva-aineluokassa KA1 PrH rehun $\mathrm{pH}$ oli suurempi kuin painorehun, kun taas kuivemmissa rehuissa $\mathrm{PrH}$ rehun $\mathrm{pH}$ oli selvästi alempana kuin painorehussa.

Maitohappokäyminen oli selvästi voimakkaampaa ymppirehuissa kuin painorehussa KA1 ja KA2 luokissa, joten myös niiden pH oli selvästi alempi kuin painorehun. Kuivimmassa rehussa ei enää muodostunut maitohappoa, joten painorehun ja ymppirehujen $\mathrm{pH}$ oli lähes sama. Sen sijaan propionihappovalmisteen oma happamuus laski pH:n muita rehuja alemmaksi $(5,29$ vs 5,85).

Maitohappokäymisen voimakkuus heijastui suoraan rehujen sokeripitoisuuteen. KA1 ja KA2 rehuissa oli selvät erot sekä maitohappo- että sokeripitoisuudessa painorehun ja säilöntäaineilla käsiteltyjen välillä ja edelleen PrH:n ja ymppirehujen välillä. Runsaamman käymisen vuoksi ymppirehuissa oli pienempi sokeripitoisuus sekä painorehuun että PrH rehuun verrattuna. Kuivimmissa rehuissa ei käymistä tapahtunut, joten sokeripitoisuudessa ei ollut merkitseviä eroja rehujen välillä.

Ammoniakin ja VFA:n muodostuminen oli hyvin rajoittunutta myös tässä kokeessa kaikissa rehuissa. Kuten edellisessä kokeessa suuret propionihapon ja ammoniakin pitoisuudet PrH rehuissa olivat seurausta säilöntäaineessa lisätyistä määristä. Etikkahapon pitoisuus oli suurempi LP-LB rehussa verrattuna $\mathrm{LP}-\mathrm{NaB}$ rehuun kuiva-aineluokissa 1 ja 2.

Koerehujen aerobinen stabiilisuus oli hyvä ensimmäisten neljän päivän aikana lukuun ottamatta LR rehua KA2 luokassa, joka alkoi lämmetä muita aikaisemmin. Paalikohtaiset erot lämpenemisessä olivat suuria ja kuiva-aineen vaikutus oli erilainen eri säilöntäkäsittelyiden yhteydessä. Tämä saattaa liittyä valmisteiden tehokkuuseroihin eri kuiva-ainepitoisuudessa tai $\mathrm{pH}$ :ssa. Kuitenkin keskimäärin paras stabiilisuus oli KA1 luokan rehuissa. Tehokkaimmin lämpenemistä esti propionihappoon perustuva säilöntäaine (kuvio 2). Koska paalien välinen vaihtelu oli suurta, merkitsevästi vähemmän lämpenemistä todettiin kahdeksan päivän jälkeen PrH-rehuissa ymppirehuihin verrattuna vain kuivimmissa rehuissa. Propionihapolla käsitellyt rehut olivat hyvin stabiileja vaikka tavoitteena ollutta säilöntäaineen annostustasoa ei saavutettu KA1 ja KA2 rehuissa. Lähes yhtä hyvä oli L. plantarumin ja Nabentsoaatin yhdistelmä. Yhdistelmän tulosta heikensi kuivin rehu, jossa $\mathrm{pH}(5,89)$ oli jo todennäköisesti liian korkea Na-bentsoaatin tehoamiseksi. L. plantarumin ja L. buchnerin yhdistelmä ei sen sijaan ollut keskimäärin yhtä varma kuin ensimmäisessä kokeessa. Osa paaleista ei lämmennyt, mutta 
muutamassa paalissa lämpeneminen oli voimakasta. Paalausmenetelmälle on tyypillistä, että paalien välillä on suurta laatuvaihtelua. Tämä voi olla seurausta erilaisesta haittamikrobien kontaminaatiosta (esimerkiksi maa-aineksen joutuminen paaliin) tai paalimuovin rikkoutumisesta. Riskiä lisää se, että paaleissa pintarehun osuus massasta on paljon suurempi kuin siilossa tai tornissa.

\section{Johtopäätökset}

Esikuivatusaika ja säilöntäaineen käyttö vaikuttavat säilöheinän laatuun. Kokeen perusteella suuri kuiva-ainepitoisuus (yli $550 \mathrm{~g} / \mathrm{kg}$ ) altistaa rehun helpommin lämpenemiselle verrattuna tuoreempaan rehuun. Suuri kuiva-ainepitoisuus myös estää biologisten säilöntäaineiden toimintaa, mikä säilyttää rehussa suuren sokeripitoisuuden ja toisaalta heikentää niiden tehoa aerobisen stabiilisuuden parantamisessa.

Säilöntäaineen käyttö parantaa rehun mikrobiologista laatua ja sitä kautta myös pienentää lämpenemisriskiä. Lämpenemisen estäjänä tehokkain oli propionihappopohjainen valmiste. Myös maitohappobakteerin ja natriumbentsoaatin yhdistelmä antaa tulosten perusteella hyvän tuloksen edellyttäen, että rehu ei ole liian kuivaa. Propionihapon käyttö ei vähentänyt säilöheinän sokeripitoisuutta säilönnän aikana. Sen sijaan maitohappobakteereiden käyttö säilöntäaineena muunsi tehokkaasti rehun sokereita maitohapoksi. Siten se on tehokas keino vähentää rehun sokereiden pitoisuutta ja myös fruktaanien pitoisuutta, jos tavoitteena on rehun sokeripitoisuuden vähentäminen hevosten ruokinnassa. Edellytyksenä on myös tässä, että rehua ei kuivata liian kuivaksi. Kuiva-ainepitoisuuden on oltava alle 550 $\mathrm{g} / \mathrm{kg}$, jotta maitohappokäymistä voi tapahtua.

\section{Kirjallisuus}

Oude Elferink, S. J., Krooneman, W. H., Gottschal, J. C., Spoelstra, S. F., Faber, F.\& Driehuis,F. 2001. Anaerobic conversion of lactic acid to acetic acid and 1,2-propanediol by Lactobacillus buchneri. Applied and Environmental Microbiology 67:125-132.

Pollitt, C. C., Kyaw-Tanner, M., French, K.R., van Eps, A.W., Hendrikz, J.K. \& Daradka, M. 2003. Equine Laminitis. American Association of Equine Practitioners Proceedings 49: 103-115.

Saarisalo, E., Jalava, T., Skyttä, E., Haikara, A. \& Jaakkola , S. 2006. Effect of lactic acid bacteria inoculants, formic acid, potassium sorbate and sodium benzoate on fermentation quality and aerobic stability of wilted grass silage. Agricultural and Food Science 15: 185-199.

Woolford, M. K. 1975. Microbiological screening of the straight chain fatty acids (C1-C12) as potential silage additives. Journal of the Science of Food and Agriculture 26: 219-228.

Taulukko 2. Säilörehujen raaka-aineiden koostumus kokeissa 1 ja 2.

\begin{tabular}{|c|c|c|c|c|c|}
\hline & \multicolumn{2}{|c|}{ Koe 1} & \multicolumn{3}{|c|}{ Koe 2} \\
\hline & Kuiva-aine 1 & Kuiva-aine 2 & Kuiva-aine 1 & Kuiva-aine 2 & Kuiva-aine 3 \\
\hline Esikuivatusaika, h & 26 & 29 & 24 & 30 & 50 \\
\hline Kuiva-aine, g/kg & 513 & 601 & 440 & 560 & 643 \\
\hline \multicolumn{6}{|l|}{ Kuiva-aineessa, g/kg } \\
\hline Tuhka & 78,7 & 76,3 & 69,9 & 70,6 & 70,0 \\
\hline Raakavalkuainen & 160 & 141 & 139 & 139 & 147 \\
\hline NDF & 595 & 584 & 561 & 567 & 549 \\
\hline Sokeri & 87,6 & 96,4 & 102 & 102 & 104 \\
\hline $\begin{array}{l}\text { Puskurikapasiteetti, } \\
\text { mekv/kg ka }\end{array}$ & 473 & 408 & 374 & 369 & 347 \\
\hline D-arvo, \% & 70,2 & 70,5 & 69,3 & 68,9 & 69,7 \\
\hline
\end{tabular}

NDF = neutraalidetergenttikuitu

D-arvo = sulavaa orgaanista ainetta kuiva-aineessa 
Taulukko 3. Säilörehujen koostumus ja käymislaatu kokeessa 1.

\begin{tabular}{|c|c|c|c|c|c|c|c|c|c|}
\hline \multirow[t]{2}{*}{ Säilöntäaine } & \multirow{2}{*}{$\begin{array}{l}\text { Kuiva- } \\
\text { aine, } \\
\text { g/kg }\end{array}$} & \multirow[t]{2}{*}{$\mathrm{pH}$} & Tuhka & Sokeri & $\begin{array}{l}\text { Maito- } \\
\text { happo }\end{array}$ & $\begin{array}{c}\text { Etikka- } \\
\text { happo }\end{array}$ & $\begin{array}{l}\text { VFA }^{1} \\
\text { yht. }\end{array}$ & \multirow{2}{*}{$\begin{array}{c}\text { Maitoh. } \\
\% \\
\text { hapoista }\end{array}$} & \multirow{2}{*}{$\frac{\mathrm{NH}_{3}-\mathrm{N}^{2}}{\mathrm{~g} / \mathrm{kg} \mathrm{N}}$} \\
\hline & & & \multicolumn{5}{|c|}{$\mathrm{g} / \mathrm{kg} \mathrm{ka}$} & & \\
\hline \multicolumn{10}{|l|}{ Kuiva-aine 1} \\
\hline Painorehu (PR) & 522 & 4,83 & 77,9 & 46,3 & 47,6 & 8,17 & 8,75 & 84,5 & 37,3 \\
\hline Propionihappo (PrH) & 526 & 4,92 & 77,2 & 60,6 & 39,7 & 8,40 & 17,88 & 68,9 & 67,5 \\
\hline $\operatorname{PrH}+$ sorbaatti $(\mathrm{PrH}-\mathrm{S})$ & 534 & 4,92 & 77,1 & 62,2 & 36,7 & 8,68 & 16,61 & 68,8 & 63,1 \\
\hline L. rhamnosus (LR-PF) & 524 & 4,37 & 77,4 & 32,5 & 66,7 & 6,45 & 6,93 & 90,6 & 35,3 \\
\hline L. plantarum (LP) & 527 & 4,32 & 77,9 & 36,7 & 72,0 & 6,45 & 6,92 & 91,2 & 25,1 \\
\hline $\mathrm{LP}+L$. buchneri $(\mathrm{LP}-\mathrm{LB})$ & 542 & 4,44 & 80,4 & 36,6 & 66,1 & 9,25 & 9,86 & 87,0 & 34,1 \\
\hline SEM & 2,8 & 0,053 & 0,23 & 2,34 & 1,52 & 0,297 & 0,339 & 0,61 & 2,52 \\
\hline PR vs säilöntäaineet & * & $* *$ & & & $* * *$ & & $* * *$ & $* * *$ & $*$ \\
\hline Hapot $v s$ ympit $^{3}$ & & $* * *$ & $* * *$ & $* * *$ & $* * *$ & $* *$ & $* * *$ & $* * *$ & $* * *$ \\
\hline $\operatorname{PrH} v s$ PrH-S & & & & & & & $*$ & & \\
\hline LR-PF vs LP, LP-LB & $*$ & & $* * *$ & & & $* *$ & $* *$ & & \\
\hline LP vs LP-LB & $* *$ & & $* * *$ & & $*$ & $* * *$ & $* * *$ & $* * *$ & $*$ \\
\hline \multicolumn{10}{|l|}{ Kuiva-aine 2} \\
\hline Painorehu (PR) & 603 & 5,48 & 74,5 & 81,4 & 13,6 & 7,12 & 7,77 & 63,6 & 26,5 \\
\hline Propionihappo (PrH) & 616 & 5,38 & 73,4 & 104,0 & 7,3 & 6,46 & 14,83 & 33,0 & 59,9 \\
\hline $\operatorname{PrH}+$ sorbaatti $(\mathrm{PrH}-\mathrm{S})$ & 611 & 5,37 & 73,3 & 99,5 & 7,7 & 6,73 & 13,69 & 36,0 & 55,6 \\
\hline L. rhamnosus (LR-PF) & 602 & 5,23 & 74,7 & 78,7 & 22,1 & 7,00 & 7,64 & 74,3 & 27,7 \\
\hline L. plantarum (LP) & 605 & 4,92 & 74,3 & 76,2 & 36,4 & 6,47 & 7,06 & 83,7 & 23,9 \\
\hline $\mathrm{LP}+$ L.buchneri (LP-LB) & 601 & 4,77 & 75,9 & 58,7 & 40,1 & 8,90 & 9,57 & 80,7 & 25,7 \\
\hline SEM & 2,9 & 0,020 & 0,32 & 1,51 & 0,82 & 0,377 & 0,391 & 1,24 & 1,71 \\
\hline PR vs säilöntäaineet & & $* * *$ & & & $* * *$ & & $* * *$ & & $* * *$ \\
\hline Hapot $v s$ ympit $^{3}$ & $* *$ & $* * *$ & $* * *$ & $* * *$ & $* * *$ & * & $* * *$ & $* * *$ & $* * *$ \\
\hline \multicolumn{10}{|l|}{ PrH vs PrH-S } \\
\hline LR-PF vs LP, LP-LB & & $* * *$ & & $* * *$ & $* * *$ & & & $* * *$ & \\
\hline LP $v s$ LP-LB & & $* * *$ & $* *$ & $* * *$ & $* *$ & $* * *$ & $* * *$ & & \\
\hline
\end{tabular}

${ }^{1,2}$ Sisältää säilöntäaineessa lisätyn propionihapon (1) ja typen (2), VFA = haihtuvat rasvahapot

${ }^{3}$ Hapot $v s$ ympit $=$ PrH, PrH-S vs LR-PF, LP, LP-LB

Tilastollinen merkitsevyys: *** $(\mathrm{P}<0,001), * *(\mathrm{P}<0,01), *(\mathrm{P}<0,05)$

Kuiva-aine $1(500 \mathrm{~g} / \mathrm{kg})$

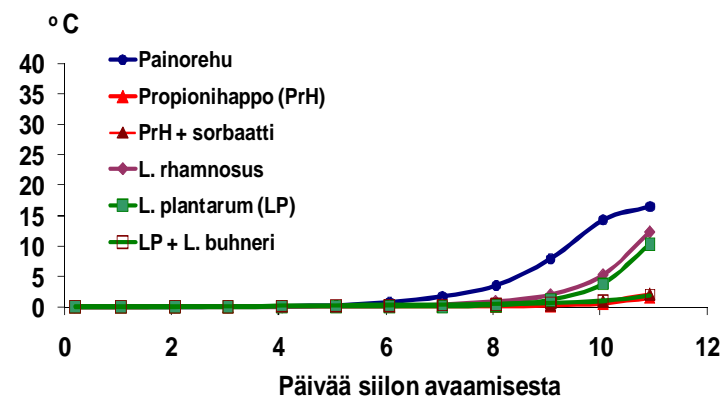

Kuiva-aine $2(600 \mathrm{~g} / \mathrm{kg})$

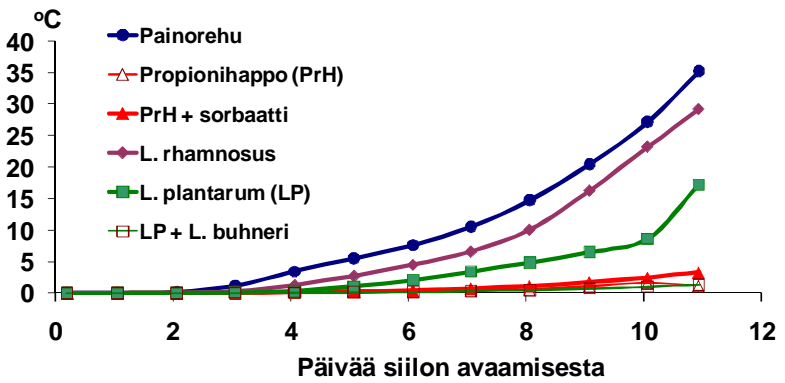

Kuvio 1. Rehujen lämpenemisalttius (aerobinen stabiilisuus) esitettynä kumulatiivisena lämpötilasummana (erotus huoneenlämpötila - näytteen lämpötila) (koe 1). 
Taulukko 4. Säilörehujen koostumus ja käymislaatu kokeessa 2. Kuiva-aineluokan 3 tuloksia ei esitettä, koska käyminen oli hyvin vähäistä.

\begin{tabular}{|c|c|c|c|c|c|c|c|c|c|}
\hline \multirow[t]{2}{*}{ Säilöntäaine } & \multirow{2}{*}{$\begin{array}{l}\text { Kuiva- } \\
\text { aine, } \\
\mathrm{g} / \mathrm{kg}\end{array}$} & \multirow[t]{2}{*}{$\mathrm{pH}$} & Tuhka & Sokeri & $\begin{array}{l}\text { Maito- } \\
\text { happo }\end{array}$ & $\begin{array}{l}\text { Etikka- } \\
\text { happo }\end{array}$ & $\begin{array}{l}\text { VFA }^{1} \\
\text { yht. }\end{array}$ & \multirow{2}{*}{$\begin{array}{c}\text { Maitoh. } \\
\% \\
\text { hapoista }\end{array}$} & \multirow{2}{*}{$\frac{\mathrm{NH}_{3}-\mathrm{N}^{2}}{\mathrm{~g} / \mathrm{kg} \mathrm{N}}$} \\
\hline & & & \multicolumn{5}{|c|}{$\mathrm{g} / \mathrm{kg} \mathrm{ka}$} & & \\
\hline \multicolumn{10}{|l|}{ Kuiva-aine 1} \\
\hline Painorehu (PR) & 476 & 4,94 & 70,5 & 95,5 & 32,8 & 6,58 & 7,35 & 81,7 & 27,3 \\
\hline Propionihappo (PrH) & 490 & 5,35 & 68,5 & 137,7 & 2,9 & 5,78 & 24,53 & 10,6 & 64,3 \\
\hline L. rhamnosus $\mathrm{R}$ (LR) & 475 & 4,17 & 67,2 & 57,7 & 75,6 & 5,56 & 6,08 & 92,5 & 26,8 \\
\hline L.plantarum+L.buchneri (LP-LB) & 472 & 4,28 & 70,2 & 51,7 & 71,9 & 7,71 & 8,33 & 89,5 & 28,4 \\
\hline LP + Na-bentsoaatti (LP-NaB) & 472 & 4,27 & 68,0 & 64,9 & 71,1 & 5,43 & 6,00 & 92,2 & 22,4 \\
\hline SEM & 3,5 & 0,061 & 0,07 & 3,77 & 3,93 & 0,432 & 1,743 & 3,10 & 4,45 \\
\hline $\begin{array}{l}\text { PR vs säilöntäaineet } \\
\text { Happo vs ympit }{ }^{3} \\
\text { LR vs LP-LB, LP-NaB } \\
\text { LP-LB vs LP-NaB }\end{array}$ & $* *$ & $\begin{array}{l}* * * \\
* * *\end{array}$ & & $\begin{array}{l}* * \\
* * *\end{array}$ & $\begin{array}{l}* * \\
* * *\end{array}$ & $* *$ & $* * *$ & $\begin{array}{c}* \\
* * *\end{array}$ & $* * *$ \\
\hline \multicolumn{10}{|l|}{ Kuiva-aine 2} \\
\hline Painorehu (PR) & 568 & 5,75 & 6,79 & 121,0 & 10,0 & 6,47 & 7,26 & 56,8 & 26,5 \\
\hline Propionihappo (PrH) & 587 & 5,17 & 6,83 & 142,4 & 2,6 & 6,11 & 35,74 & 6,7 & 91,7 \\
\hline L. rhamnosus $\mathrm{R}$ (LR) & 563 & 4,94 & 6,51 & 98,4 & 36,4 & 5,92 & 6,53 & 84,4 & 27,4 \\
\hline L.plantarum+L.buchneri (LP-LB) & 562 & 4,40 & 6,70 & 57,3 & 57,2 & 8,49 & 9,22 & 86,1 & 26,2 \\
\hline LP + Na-bentsoaatti (LP-NaB) & 555 & 4,78 & 6,74 & 96,6 & 39,7 & 6,57 & 7,18 & 84,4 & 22,2 \\
\hline SEM & 3,7 & 0,109 & 0,123 & 3,69 & 3,19 & 0,280 & 0,385 & 2,58 & 1,92 \\
\hline PR $v s$ säilöntäaineet & & $* * *$ & & $* *$ & $* * *$ & & $* * *$ & $*$ & $* * *$ \\
\hline Happo $v s$ ympit $^{3}$ & $* * *$ & $* *$ & & $* * *$ & $* * *$ & $* *$ & $* * *$ & $* * *$ & $* * *$ \\
\hline LR vs LP-LB, LP-NaB & & $*$ & & $* *$ & $*$ & $* * *$ & $* *$ & & \\
\hline LP-LB $v s$ LP-NaB & & $*$ & & $* * *$ & $* *$ & $* * *$ & $* *$ & & \\
\hline
\end{tabular}

${ }^{1,2}$ Sisältää säilöntäaineessa lisätyn propionihapon (1) ja typen (2), VFA = haihtuvat rasvahapot

${ }^{3}$ Hapot $v s$ ympit $=$ PrH, PrH-S vs LR-PF, LP, LP-LB

Tilastollinen merkitsevyys: *** $(\mathrm{P}<0,001), * *(\mathrm{P}<0,01), *(\mathrm{P}<0,05)$

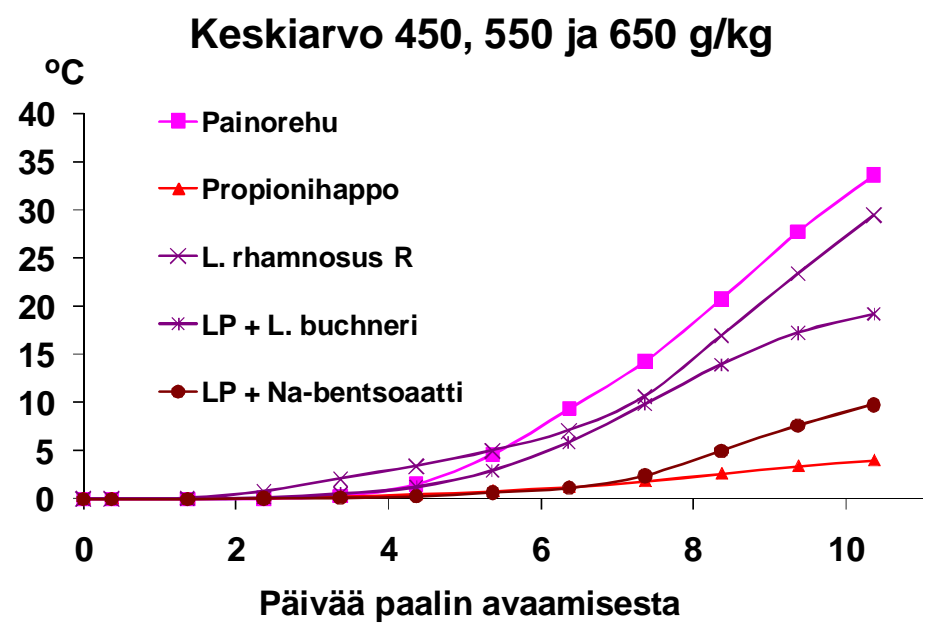

Kuvio 2. Kaikkien koerehujen keskimääräinen lämpenemisalttius (aerobinen stabiilisuus) esitettynä kumulatiivisena lämpötilasummana (erotus huoneenlämpötila - näytteen lämpötila) (koe 2). 